\title{
(बR
}

\section{A Rare Case: Spontaneous Uterine Rupture in First Pregnancy}

\author{
Nadir Bir Olgu: Ilk Gebelikte Spontan Uterus Rüptürü
}

\author{
Gökhan Aksel', Aslı Bilge Kanber Deniz', Özlem Güneysel²
}

'Department of Emergency Medicine, Ümraniye Training and Research Hospital, İstanbul, Turkey

2Department of Emergency Medicine, Dr. Lütfü Kırdar Kartal Training and Research Hospital, İstanbul, Turkey

\begin{abstract}
Introduction: Spontaneous uterine rupture is potentially catastrophic for both the mother and fetus. It is associated with risk factors, such as uterine abnormalities, uterine scar, macrosomic fetus, cephalopelvic disproportion, and use of uterotonic agents for induction of labor. We present a case of spontaneous rupture of an unscarred primigravid uterus, which is extremely rare.
\end{abstract}

Case Report: A 22-year-old primigravida at 22 weeks presented to the emergency department with complaints of syncope and mild dyspnea. On her physical examination, she had a Glasgow coma scale of 15, tension arterial of $60 / 30 \mathrm{mmHg}$, and pulse rate of 110 beats/minute. Her first abdominal ultrasound was reported as normal. After consultation, the obstetrician reported that the fetus had normal fetal heart rate, and there had been no abnormality with the patient's pregnancy. After intravenous infusion of 1000 $\mathrm{ml}$ saline, her hypotension still proceeded, and her second USG revealed free fluid in the abdomen. An emergency laparotomy was performed for a probable diagnosis of intra-abdominal hemorrhage and the fetus found floating freely in the peritoneal cavity. The patient recovered and discharged healthy 5 days after the operation, while the fetus could not survive.

Conclusion: Although it is extremely rare in primigravidas, an emergency physician should consider spontaneous uterine rupture in pregnant patients with hemodynamic instability.

Keywords: Spontaneous, uterus, rupture, pregnant

Received: 25.06.2014 Accepted: 27.08.2014

\section{ÖZET}

Giriş: Gebeliğin çok nadir bir komplikasyonu olan spontan uterus rüptürü hem fetus hem de anne için oldukça katastrofiktir. Bu durum, uterus anomalileri, uterin skar dokusu varlığı, makrozomik fetüs, sefalopelvik uyuşmazlık ve doğum esnasında indüksiyon ajanları kullanıması gibi risk faktörleri ile ilişkilidir. Bu yazıda oldukça nadir görülen, ilk gebelikte gelişen, travma öyküsü olmayan skarsız bir uterus rüptürü vakasını tartışmayı amaçladık.

Olgu Sunumu: 22 yaşında ve 22 haftalık ilk gebeliği olan hasta acil servise bayılma ve hafif dispne şikayetleri ile başvurdu. Hastanın travma öyküsü yoktu. Fizik muayenesinde Glasgow koma skoru 15, arteriyel tansiyonu 60/30 mmHg ve nabız sayısı 110/dakika idi. Yapılan ilk abdominal ultrason sonucu normal olarak değerlendirildi. Kadın hastalıkları ve doğum uzmanına toplamda 2 defa konsülte edilen hastada fetal kalp atımlarının normal olduğu ve obstetrik bir patoloji düşünülmediği bilgisi alındı. 1000ml normal salin infüzyonuna rağmen hipotansiyonu devam eden hastanın yapılan kontrol ultrasonunda batın içerisinde serbest sıvı tespit edildi. Bunun üzerine genel cerrahi tarafından tanısal amaçlı acil laparotomy uygulanan hastada batın içerisinde önemli miktarda kanama olduğu ve fetüsün peritoneal kavitede olduğu görüldü. Hasta operasyon sonrasında iyileşip, post operatif 5. günde taburcu edilirken fetus kaybedildi.

Sonuç: Her ne kadar primigravidlerde çok nadir görülse de, acil servis doktorları hemodinamik olarak unstabil olan gebe hastalarda spontan uterus rüptürünü akla getirmelidirler.

Anahtar Kelimeler: Spontan, uterus, rüptür, gebe

Geliş Tarihi: 25.06.2014 Kabul Tarihi: 27.08.2014 


\section{Giriş}

Uterus rüptürleri 3 gruba ayrılmaktadır: 1-) daha önceki sezaryen skarı bulunan uterusun rüptürü, 2-) intakt uterusun travmatik rüptürü ve 3-) intakt olan uterusun spontan rüptürü (1). Uterus rüptürü genellikle uterus anomalileri, beş ve daha fazla gebelik, makrozomik fetüs, sefalopelvik uyumsuzluk, oksitosin uygulanması ve travma gibi risk faktörleri varlığında gerçekleşmektedir. Bununla beraber en sık rüptür sebebi ise eski skar dokusu bulunan ve tanı almamış sefalopelvik uyumsuzluk olan hastada oksitosinle indüklenme olarak gösterilmektedir. Skarsız bir uterusun spontan rüptürü oldukça nadirdir ancak hem fetüs hem de anne için oldukça mortal seyreden bir durumdur $(2,3)$.

Biz bu olgu sunumu ile literatürde az sayıda bildirilmiş olan ilk gebelik esnasında gelişen, doğum eylemi ile ilişkisiz spontan uterus rüptürü vakasını tartışmayı amaçladık.

\section{Olgu Sunumu}

22 yaşında ve 22 haftalık ilk gebeliği olan kadın hasta Acil servise (AS) bayılma şikayeti ile başvurdu. AS başvurusundan 1 saat önce mutfağa su içmek için gittiğinde önce göz kararması olmuş ve sonrasında bayılmış. Yaklaşık 2 dakika bilinçsiz halde olduğu ifade edilen hastanın herhangi bir travma öyküsü olmadığı öğrenildi. Hafif nefes darlığı şikayeti bulunan hastanın karın ağrısı, vajinal kanama şikayetleri yoktu. Özgeçmişinde herhangi bir hastalığı olmadığı öğrenildi. AS başvurusu sırasında hastanın nabzı:110/ dk, arteriyel tansiyon (AT): 60/30 mmHg olarak ölçüldü. Fizik muayenesinde Glasgow koma skoru (GKS) 15 olarak değerlendirilen ancak hafif uykuya meyilli olan hastanın diğer sistem muayeneleri doğaldı. Laboratuar tetkik sonuçlarında hemogramda Hb:11 g/ dL, lökosit sayısı 19,4 K/uL olarak tespit edildi. Kan biyokimyası ve venöz kan gazı tetkik sonuçları normal olan hastaya 1000 ml \%0.9 serum fizyolojik intravenöz bolus olarak verildi. Sıvı resüsitasyonu sonrasında AT 90/50 mmHg olan ve yapılan hasta başı ultrasound (USG) değerlendirmesinde batın içerisinde serbest sıvı saptanmayan hasta kadın hastalıkları ve doğum (KHD) bölümü ile konsülte edildi ve fetal kalp atımının (FKA) normal olduğu, hastada obstetrik açıdan herhangi bir patoloji düşünülmediği bilgisi alındı. Takibinde AT:80/40 mmHg'ya gerileyen hastada üterin rüptür ön tanısıyla ikinci defa KHD konsültasyonu istendiyse de yine ilgili bölümden hastada obstetrik açıdan herhangi bir acil patoloji düşünülmediği görüşü alındı. Kontrol hemogram sonucunda $\mathrm{Hb}: 8 \mathrm{~g} / \mathrm{dL}$ olan, hipotansiyonu devam eden ve ilk USG'den 30 dakika sonra tekrarlanan kontrol batın USG'sinde serbest sıvı saptanan (Resim 1) hasta genel cerrahi bölümü ile konsülte edildi ve acil operasyona alındı. Operasyonda uterin rüptür olduğu tespit edildi ve fetüs alınarak, gebelik sonlandırıldı. Uterus duvar tamiri yapılan ve kanama kontrolü sonrasında stabil seyreden hasta postoperatif beşinci gününde sağlıklı şekilde taburcu edildi.

\section{Tartışma}

Geleneksel olarak primigravid olan ve öncesine ait skar dokusu bulunmayan uterusun spontan rüptür riski düşük olarak kabul edilir. Eski skar olmaksızın uterus rüptürü daha önce çok az sayıda

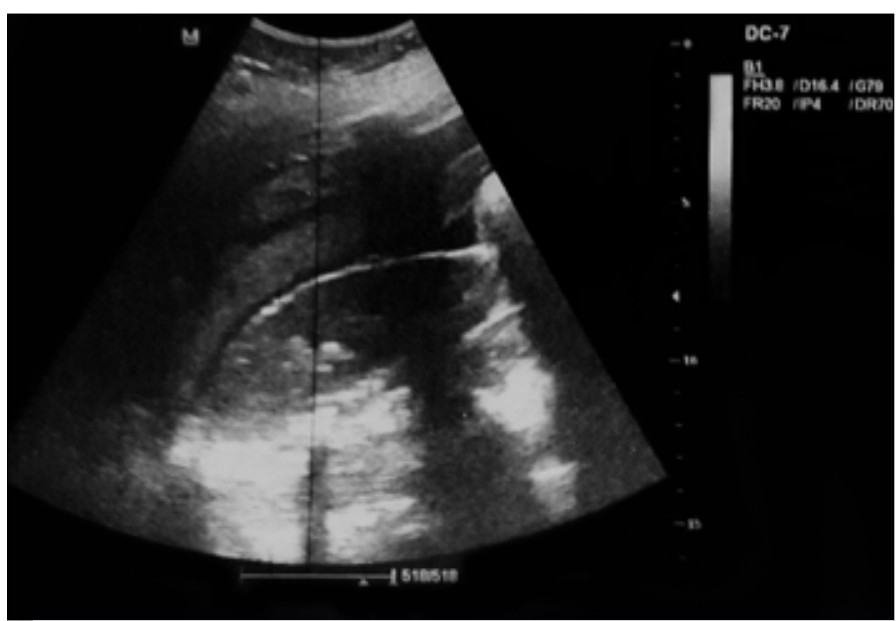

Resim 1. Hastanın ultrason görüntüsü. Morrison boşluğunda serbest sıvı görülmekte

bildirilmiş olup bunların hemen hepsi doğum sırasında meydana gelmiştir. Bu olguların çoğu sefalopelvik uyumsuzluk, oksitosin indüksiyonu veya invitro fertilizasyon denemesi gibi risk faktörler varlığında gerçekleşmiştir $(1,4)$. Doğumla ilişkili olmaksızın ve daha öncesine ait skar dokusu, travma öyküsü olmayan spontan uterus rüptürü ise yok denecek kadar az sayıda bildirilmiştir. $(2,5)$.

Hastanın ilk gebeliği olması, travma öyküsü olmaması, karın ağrısı veya vajinal kanama gibi semptomların olmaması nedeniyle ilk değerlendirmede akla uterus rüptürü gelmemiştir. Yapılan 2 KHD konsültasyonunda da FKA'nın normal olduğu tespit edilmiştir. Oysa Ayres ve ark. çalışmalarında uterin rüptürlerin \%80'inde rüptürden yaklaşık 2 saat önce başlayan FKA hızında azalma olduğunu bildirilmişlerdir (6). Önceki çalışmalarda FKA'nın hızında azalma üterus rüptürünün erken habercisi olduğu vurgulanırken bu olguda beklenenin aksine FKA hızının normal olması tanının gecikmesine sebep olmuştur. Spontan uterin rüptür tanısı koymak oldukça zor olup çoğu zaman USG ve tomografi de yeterli olmayabilmektedir ki bazı yazarlar manyetik rezonans görüntülemenin diğer görüntüleme yöntemlerine üstün olabileceğini belirtmektedirler. Mizutamari ve ark. da 32 haftalık spontan uterus rüptürü olan bir gebede FKA'nın tamamen normal olduğu bilgisini vererek hastanın vital stabilitesi ve klinik uyumsuzluğu sebebiyle tanıyı koymakta zorlandıklarını ancak manyetik rezonans görüntüleme ile tanı koyabildiklerini bildirmişlerdir $(7,8)$. Bu olguda, FKA'nın normal olmasının yanı sıra hastanın yapılan ilk USG'nin normal olarak değerlendirilmesi de tanı koymayı güçleştirmiştir.

Uterus rüptürü tanısı konan gebede tedavi erken cerrahi girişimdir. Seçilecek cerrahi yöntem hastanın yaşına, gebelik sayısına ve ileride tekrar çocuk sahibi olmak isteyip istememesine göre değişmektedir. Eskiden bu hastalara sadece histerektomi önerilmekteyken artık tekrar çocuk sahibi olmak isteyen kadınlarda rüptüre olan uterusun tamir edilmesi de tedavi seçenekleri arasında bulunmaktadır (9). Bu hastanın genç olması, ilk gebeliği olması ve tekrar çocuk sahibi olma isteği sebebiyle rüptüre olan uterus duvarı tamir edilmiştir. 
Ancak bu hastalara, sonraki tüm gebeliklerinde uterus rüptürünün tekrarlayabileceği ve sezaryen ile doğum yapmaları gerekliliği açıkça anlatılmalıdır (10).

\section{Sonuç}

Her ne kadar ilk gebelikte spontan uterus rüptürü çok nadir görülse de, şok bulguları ile başvuran bir gebede tüm resüsitatif çabalara rağmen hemodinamik stabilizasyon sağlanamıyorsa hastada uterus rüptürü mutlaka akla gelmelidir. Bu hastalarda FKA'nın normal olabileceği, ilk değerlendirme sırasında USG'nin hatta bazen tomografinin dahi tanısal olamayabileceği unutulmamalıdır.

Informed Consent: Written informed consent was not obtained from patient who participated in this case.

Peer-review: Externally peer-reviewed.

Author Contributions: Concept - G.A.; Design - Ö.G.; Supervision - Ö.G.; Materials - ABKD; Data Collection and/or Processing - ABKD.; Analysis and/or Interpretation - G.A.; Literature Review - G.A.; Writer - G.A.; Critical Review - Ö.G.

Conflict of Interest: The authors declared no conflict of interest.

Financial Disclosure: The authors declared that this study has received no financial support.

Hasta Onamı: Yazılı hasta onamı bu olguya katılan hastadan alınmamıştır.

Hakem Değerlendirmesi: Dış bağımsız.

Yazar Katkıları: Fikir - G.A.; Tasarım - Ö.G.; Denetleme - Ö.G.; Malzemeler - ABKD.; Veri toplanması ve/veya işlemesi - ABKD; Analiz ve/veya yorum -G.A.; Literatür taraması - G.A.; Yazıyı yazan - G.A.; Eleştirel İnceleme - Ö.G.

Çıkar Çatışması: Yazarlar çıkar çatışması bildirmemişlerdir.

Finansal Destek: Yazarlar bu çalışma için finansal destek almadıklarını beyan etmişlerdir.

\section{Kaynaklar}

1. Sweeten KM, Graves WK, Athanassiou A. Spontaneous rupture of the unscarred uterus. Am J Obstet Gynecol 1995; 172: 1851-5; discussion 1855-6. [CrossRef]

2. Langton J, Fishwick K, Kumar B, Nwosu EC. Spontaneous rupture of an unscarred gravid uterus at 32 weeks gestation. Hum Reprod 1997; 12: 2066-7.

3. Golan A, Sandbank O, Rubin A.Rupture of the pregnant uterus. Obstet Gynecol 1980; 56: 549-54.

4. Uccella S, Cromi A, Bogani G, Zaffaroni E, Ghezzi F. Spontaneous prelabor uterine rupture in a primigravida: a case report and review of the literature. Am J Obstet Gynecol 2011; 205: e6-8. [CrossRef]

5. Abbi M, Misra R. Rupture of uterus in a primigravida prior to onset of labor.Int J Fertil Womens Med 1997; 42: 418-20.

6. Ayres AW, Johnson TR, Hayashi R. Characteristics of fetal heart rate tracings prior to uterine rupture. Int J Gynaecol Obstet 2001; 74: 235-40. [CrossRef]

7. Mizutamari E, Honda T, Ohba T, Katabuchi H. Spontaneous rupture of an unscarred gravid uterus in a primigravid woman at 32 weeks of gestation. Case Rep Obstet Gynecol 2014; 2014: 209585. doi: 10.1155/2014/209585. Epub 2014 Jun 30. [CrossRef]

8. Hruska KM, Coughlin BF, Coggins AA, Wiczyk HP. MRI diagnosis of spontaneous uterine rupture of an unscarred uterus. Emerg Radiol 2006; 12: 186-8. [CrossRef]

9. Guèye M, Mbaye M, Ndiaye-Guèye MD, Kane-Guèye SM, Diouf AA, Niang MM et al. Spontaneous Uterine Rupture of an Unscarred Uterus before Labour. Case Rep Obstet Gynecol 2012; 2012: 598356.

10. Conturso R, Redaelli L, Pasini A, Tenore A. Spontaneous uterine rupture with amniotic sac protrusion at 28 weeks subsequent to previous hysteroscopic metroplasty. Eur J Obstet Gynecol Reprod Biol 2003; 107: 98-100. [CrossRef] 